\title{
Who Had Their Cake and Ate It? Lessons from the UK's Withdrawal Process and its Impact on the Post-Brexit Trade Talks
}

\author{
Polly R. Polak \\ Public International Law and European Law Department, University of Salamanca, Spain \\ Corresponding author: pollypolak@usal.es
}

(Received 05 December 2020; accepted 04 January 2021)

\begin{abstract}
This Article highlights the legal and procedural restrictions a Member States faces during its withdrawal from the EU and subsequent talks on a future trade relationship by analyzing the unprecedented case of the UK. One such restriction consists of an obligation to negotiate withdrawal as a result of the principle of sincere cooperation. Other limits derive from the withdrawal process itself, designed as it was by the European institutions on the basis of a very scant Article 50 TEU. By then comparing the three substantive pillars of the EU-UK WA - citizens' rights, the financial settlement, and the Irish border — with the UK's initial negotiating red lines, I offer two conclusions: That the aforementioned constraints on the withdrawing state can significantly weaken the defense of its interests during its withdrawal process and that having to agree to important issues in a first and separate stage of "orderly withdrawal" talks also diminishes the state's bargaining power with regards to the next stage of negotiating a future partnership with the EU.
\end{abstract}

Keywords: Brexit; Article 50; Withdrawal Agreement; Future Trade Talks; Negotiations

\section{A. Introduction}

Since the entry into force of the Lisbon Treaty, there is one clear restriction placed upon a Member State wishing to leave the European Union (EU), which most if not all scholars agree to: That it must use Article 50 of the Treaty on European Union (TEU) as lex specialis and any attempt at an exit through other means would be in breach of both EU and international law. ${ }^{1}$ This, in turn, raises the question of how a state's withdrawal from the EU is affected by the need to follow this Treaty provision of Union law, which has replaced the general rules of international treaty termination. Although the doctrine in this case has been more contested, we can now propose better informed answers by studying the Brexit process. Indeed, the United Kingdom's (UK) unprecedented triggering of Article 50 TEU has revealed a number of other restrictions a state must contend with when attempting to withdraw from the Union. The first stems from the fact that

Polly R. Polak is a PhD in EU Law and Lecturer on EU Law \& International Relations at University of Salamanca (Spain). She is a British national and focuses her research on the legal regime of Member State withdrawal from the EU in light of Brexit.

${ }^{1}$ See generally Christophe Hillion, Accession and Withdrawal in the Law of the European Union, in THE OXFORD Handbook of European Union Law 149 (Antony Arnull \& Damian Chalmers eds., 2015). See also Jean-Claude Piris, If the UK Votes to Leave: The Seven Alternatives to EU Membership, CER (Jan. 12, 2016), https://cer.eu/publications/ archive/policy-brief/2016/if-uk-votes-leave-seven-alternatives-eu-membership; Vernon Bogdanor, Brexit, the Constitution and the Alternatives, 27 KING'S L. J. 314, 315 (2016).

(C) The Author(s) 2021. Published by Cambridge University Press on behalf of the German Law Journal. This is an Open Access article, distributed under the terms of the Creative Commons Attribution licence (http://creativecommons.org/licenses/by/4.0/), which permits unrestricted re-use, distribution, and reproduction in any medium, provided the original work is properly cited. 
inserting a withdrawal clause in the Treaties requires it to be interpreted in the integrationist spirit of Union law with due regard to its fundamental principles. Brexit has highlighted that when it comes to withdrawal, the most significant EU principle is that of sincere cooperation, Article 4(3) TEU, which tempers the unilateral character of the right to withdraw by obliging the withdrawing party to help the Union fulfil its mandate of negotiating and concluding a withdrawal agreement. Second, because the European institutions are put in charge of the negotiations-a considerable anomaly when compared to standard treaty withdrawal among states-it has allowed the EU to capitalize on the rudimentary nature of Article $50 \mathrm{TEU}$ and fill in its legal gaps with rules that naturally favor its side of the negotiations to the detriment of the defecting state's. This can be proven by highlighting the obvious differences between the UK's initial negotiating red lines and the final content of its Withdrawal Agreement (WA or EU-UK WA). ${ }^{2}$

Furthermore, the EU's unilateral design of the withdrawal process has not only allowed it to defend its own interests during the negotiations of the initial divorce deal but also to pre-condition the future trade talks. Indeed, a strict separation between the two removed important bargaining chips from the UK's hands as it was compelled to agree on citizens' rights, a financial settlement and a solution to the Irish border before it was allowed to move on to other important issues such as security or financial services. The disadvantage of not being able to offer trade-offs between the content of its WA and that of the future partnership has recently been evidenced by how the trade talks between the EU and the UK have developed. In this sense, the UK Prime Minister's (PM) threat to breach obligations under the WA whilst the negotiations toward the future trade agreement were ongoing indicated, albeit bizarrely, that the UK hoped to use the already in force Irish Protocol toward achieving concessions by the EU in the trade negotiations: If these were not to the satisfaction of the UK, then certain provisions of the WA might be reinterpreted unilaterally. In other words, it was a dubious strategy towards recovering some of the negotiating power lost in the process of withdrawal.

The aim of this Article is to extract lessons from the UK's withdrawal from the EU by analyzing the unprecedented application of Article 50 TEU and, more specifically, by highlighting the limitations or restrictions the withdrawing state has faced during its divorce process and subsequent talks on the future trade relationship. In this sense, I will begin by considering if such restrictions consisted of an obligation to negotiate its withdrawal under the principle of sincere cooperation in Section B. Next, I will focus on extracting any limitations that might have derived from the withdrawal process itself in Section C. By then comparing the three substantive pillars of the EU-UK WA - citizens' rights, the financial settlement, and the Irish border- with the UK's initial negotiating red lines in Section D, I can offer two conclusions in Section E. The first is that the aforementioned constraints on the withdrawing state significantly weakened the defense of its interests during its withdrawal from the EU. The second is that agreeing to important issues in a first and separate stage of "orderly withdrawal" talks had the necessary consequence of diminishing the UK's bargaining power with regards to the next withdrawal stage of negotiating a future partnership with the Union.

\section{B. The Obligation to Negotiate Withdrawal under Article 50 TEU and Article 4(3) TEU}

Concerning the need to negotiate withdrawal from the EU, there are two different views: The first argues that an exiting state can simply notify and then sit out the two-year wait in Article 50, making no attempt to negotiate or seek an agreed withdrawal before leaving with no deal. ${ }^{3}$

\footnotetext{
${ }^{2}$ Council Decision 2020/135 of Jan. 31, 2020, On the Conclusion of the Agreement on the Withdrawal of the United Kingdom of Great Britain and Northern Ireland from the European Union and the European Atomic Energy Community, 2020 O.J. (L 29) 7.

${ }^{3}$ Among others, Gavin Phillipson, A Dive into Deep Constitutional Waters: Article 50, the Prerogative and Parliament, 79 MoD. L. REV. 1064, 1067 (2016).
} 
This is the result, it is argued, of the possibility envisaged by the TEU of a departure without a withdrawal agreement or, in other words, of the unilateral character of the right to withdraw. ${ }^{4}$ The second and alternate view assesses withdrawal in light of the spirit of the Treaties and the commitments made by its parties over the decades, providing a reading more in tune with the EU's supranational character. ${ }^{5}$ It sees unilateral withdrawal from the Union only as a last resort option allowed once a bona fide attempt at consensual departure has been attempted but has unfortunately failed. ${ }^{6}$

From the travaux préparatoires, we know that the final amendments to ex Article I-60 of the Constitutional Treaty, now Article 50 TEU, were envisaged to encourage a consensual outcome: Although it was accepted that withdrawal could not be restricted to cases in which an agreement was reached, the possibility of extending the two-year negotiating period was intended to prompt the drafting of an agreement. ${ }^{7}$ Likewise, the agreement resulting from the negotiations is "concluded on behalf of the Union by the Council, acting by a qualified majority, after obtaining the consent of the European Parliament." ${ }^{8}$ Although there is a clear parallel between accession and withdrawal, ${ }^{9}$ when it comes to a consensual departure, that is, the conclusion of a withdrawal agreement, Article 50 has not imitated the very demanding procedure of Article 49 TEU which subjects accession to ratification by each Member State. This is another sign that the drafters of the withdrawal clause intended to constrain unilateral withdrawal in favor of an agreed exit, making an agreement easier to reach than under general treaty law. In the terms used by the withdrawal clause itself, it is only "failing that" that a unilateral withdrawal can be exercised. ${ }^{10}$

Furthermore, Article 50 TEU does not operate in a legal vacuum but deserves a reading in accordance with the generally established principles governing the interpretation of EU law. Consequentially, it should also be interpreted in light of the principle of sincere cooperation laid down in Article 4(3) TEU. ${ }^{11}$ This principle provides for an obligation of Member States to actively ensure compliance with the EU Treaties, facilitate the achievement of Union tasks, and refrain from any contravening measures which could jeopardize the attainment of the Union's objectives. Turning to the practical implications for withdrawal of this principle, what is certain is that the European institutions do not only have to favor a consensual withdrawal but, in fact, have a clear obligation to negotiate and conclude an agreement pursuant to the second sentence of paragraph 2 of Article 50 TEU: "In the light of the guidelines provided by the European Council, the Union shall negotiate and conclude an agreement with that State, setting out the arrangements for its withdrawal, taking account of the framework for its future relationship with the Union." 12 This is a direct mandate that means once notification is received, it triggers an obligation

\footnotetext{
${ }^{4}$ Alberto López Basaguren, Brexit: la secesión de la Unión Europea entre teoría y realidad, 40 TEORÍA Y REALIDAD Constitucional 111, 117 (2017).

${ }^{5}$ Adam Łazowski, Withdrawal from the European Union and Alternatives to Membership, 37 EUR. L. REV. 523,525 (2012).

${ }^{6}$ Cristophe Hillion, Article 50 TUE - analyse juridique, 52 RTDEUR 719, 727 (2016).

7 Praesidium considers that, since many hold that the right of withdrawal exists even in the absence of an explicit provision to that effect, withdrawal of a Member State from the Union cannot be made conditional upon the conclusion of a withdrawal agreement. Hence the provision that withdrawal will take effect in any event two years after notification. However, in order to encourage a withdrawal agreement between the Union and the State which is withdrawing, Article I-57 provides for the possibility of extending this period by common accord between the European Council and the Member State concerned.

The European Convention, Draft Constitution, Volume I - Revised text of Part One, CONV 724/03 (May 28, 2003), http:// european-convention.europa.eu/pdf/reg/en/03/cv00/cv00724.en03.pdf; See also Phedon Nicolaides, Is Withdrawal from the European Union a Manageable Option? A Review of Economic and Legal Complexities, 28 BEEP 1, 3 (2013).

${ }^{8}$ Consolidated Version of the Treaty on European Union art. 50(2), Oct. 26, 2012, 2012 O.J. (C 326) [hereinafter TEU].

${ }^{9}$ See generally Hillion, supra note 1.

${ }^{10}$ TEU, supra note 8 , at art. 50(3).

${ }^{11}$ See generally Piet Eeckhout \& Eleni Frantziou, Brexit and Article 50 TEU: A Constitutionalist Reading, 54 C.M.L.R. 695 (2017).

${ }^{12}$ Article 50(2) TEU (emphasis added).
} 
addressed to the Union to negotiate an agreement with the departing state. Although from a first reading it might not seem to include the withdrawing member, it itself is under a duty to help the institutions carry out their tasks, in this case, of negotiating the departure. Indeed, because the exit clause postpones withdrawal for two years, the Member State remains bound by the Treaties until its withdrawal is final and thus remains obliged more specifically by Article 4(3) TEU to facilitate the Union's achievement of reaching a negotiated withdrawal. ${ }^{13}$

The idea that the EU withdrawal clause should be applied in the spirit of the Treaties and in compliance with the general principles of EU law has become more obvious with its unprecedented use by the UK. The UK's notification of its intention to withdraw came in the form of a letter by the UK PM addressed to the President of the European Council on March 29, 2017. ${ }^{14}$ This letter takes for granted that activation leads to discussions directed at concluding an agreement as envisaged in paragraph 2 of Article 50. There is no suggestion that this was a choice of the British authorities but more an inherent effect of notifying the intention of withdrawal pursuant to EU law. More interestingly, the UK government proposes some principles in its letter to help shape the negotiations. The first of them is that the parties "should engage with one another constructively and respectfully, in a spirit of sincere cooperation." ${ }^{15}$ Thus, this first understanding by a defecting Member State of Article 50 corroborates our notion that the obligations of loyalty deriving from the principle of sincere cooperation should be given due regard during withdrawal and that the natural result of sending the notification is to follow it with at least two years of negotiations as set out in the remainder of the clause. In effect, the notification was followed by three and a half years of Brexit talks.

In response to the Member State's notification, the European Council drafted and published its Guidelines for negotiations, highlighting the core principles of the Union's position. These were essentially two. The first principle consisted of a two-phased approach which would give priority to an "orderly withdrawal." The second principle was that of sincere cooperation. This was specifically due to the fact that, according to the European Council, until the official leave date, the UK remained a full Member of the EU, subject to all rights and obligations set out in the Treaties. Thus, although the mentioned Guidelines recognize the need to take into account the specificities of the United Kingdom as a withdrawing Member State, this would only be done "provided it respects its obligations and remains loyal to the Union's interests while still a Member." 16

I draw two preliminary conclusions from this interpretation of Article 50 TEU: First, that the obligation of sincere cooperation, which has long been recognized as a general principle which applies in all constellations under Union law, ${ }^{17}$ has now been established as a fundamental and structural principle underpinning the procedure of withdrawal from the EU. The importance given by the parties to this principle is recognition that the Treaty withdrawal mechanism does indeed favor mutually agreed exit over unilateral withdrawal, requiring the EU and the withdrawing state to make a best endeavors attempt at concluding a deal. ${ }^{18}$ Let us recall that even if they should fail to do so within the two-year timeframe, there is still the possibility of extending the

\footnotetext{
${ }^{13}$ Of the same opinion: John Weerts, L'évolution du droit de retrait de l'Union européenne et sa résonance sur l'intégration européenne, 48 CDE 345, 393 (2012); Takis Tridimas, Article 50: An Endgame Without an End?, 27 KING's L. J. 297,306 (2016).

${ }^{14}$ The United Kingdom's Prime Minister's Letter to Donald Tusk, President, European Council, Triggering Article 50 (Mar. 29, 2017), https:/gov.uk/government/publications/prime-ministers-letter-to-donald-tusk-triggering-article-50.

${ }^{15} I d$.

${ }^{16}$ European Council Guidelines Following the United Kingdom's Notification Under Article 50 TEU (Apr. 29, 2017) EUCO XT 20004/17.

${ }^{17}$ See generally Marcus Klamert, The Principle of Loyalty in EU Law (Oxford Univ. Press ed., 2014).

${ }^{18}$ An idea shared by Advocate General Manuel Campos Sánchez-Bordona in Opinion of Advocate General Bot at n. 70, Case C-621/18, Wightman v. Sec'y of State for Exiting the Eur. Union, 2018 EUR-Lex CELEX LEXIS 999 (Dec. 4, 2018): “At most, the principle of sincere cooperation would oblige the departing State to commence negotiations with the European Union in order to set the terms of withdrawal, although this as an obligation as to conduct, and not as to the result to be achieved." See Giuseppe Martinico \& Marta Simoncini, Wightman and the Perils of Britain's Withdrawal, 21 GER. L.J. 799, 813 (2020).
} 
negotiating period. Interestingly, the last extension granted to Theresa May also referred to the principle of loyal cooperation in the following terms:

The European Council takes note of the commitment by the United Kingdom to act in a constructive and responsible manner throughout the extension period in accordance with the duty of sincere cooperation, and expects the United Kingdom to fulfil this commitment and Treaty obligation in a manner that reflects its situation as a withdrawing Member State. To this effect, the United Kingdom shall facilitate the achievement of the Union's tasks and shall refrain from any measure which could jeopardize the attainment of the Union's objectives, in particular when participating in the decision-making processes of the Union. ${ }^{19}$

The second conclusion is that the duty to negotiate is not only a limitation on the departing state's right to withdraw unilaterally but also fundamentally weakens a withdrawing state's negotiating position from the start of its withdrawal process. Indeed, a Member State with an obligation to seek a divorce deal does not have the most basic bargaining tool in difficult negotiations, that is, the ability to walk away or at least credibly threaten to do so. ${ }^{20}$ Of course, leaving the negotiating table in the case of EU withdrawal is also fairly unrealistic in economic and political terms, but the fact that it would violate EU law takes away any remaining credibility to the threat. ${ }^{21}$ Thus, the British government's early declarations assuring that "no-deal is better than a bad deal"22 were not repeated in May's Article 50 letter. ${ }^{23}$ It is likely the high profile no deal Brexit had in the UK was more a bluff directed at domestic audiences than at the other party to the negotiations. ${ }^{24}$ On the contrary, the anomaly of not being able to walk away without a deal, which furthermore, had to be negotiated under the terms of Article 50 TEU as interpreted by the EU, has permeated the entire Brexit process, including the future trade talks.

\section{Restrictions Deriving from the Withdrawal Process}

Once we have established that, for any Member State wishing to leave the EU after 2009, the Article 50 procedure is the only legal route to withdrawal, and that it entails a best endeavors obligation under the duty of cooperation to strive towards a consensual exit, we find that further restrictions stem from this double reality. Indeed, Brexit not only put into play Article 50 for the first time but also highlighted how unprepared this provision was for such an immensely complex procedure. At the same time, because Member State withdrawal is not a negotiation carried out between the parties to the EU Treaties but between the withdrawing state and the European institutions, the EU has been in charge of filling in the legal gaps. This it mainly did by establishing a set of pre-notification principles and deciding on the structure of the withdrawal talks, both done quite understandably in its own interests as well as with a lasting impact that stretched beyond the Withdrawal Agreement to condition also the future trade negotiations.

\footnotetext{
${ }^{19}$ Council Decision 2019/584 of April 11, 2019, Taken in Agreement with the United Kingdom of 11 April 2019 Extending the Period under Article 50(3) TEU, 2019 O.J. (L 101).

${ }^{20}$ Cecilia Albin, Justice and Fairness in International Negotiation 1-23 (Cambridge Univ. Press ed., 2001).

${ }^{21}$ On the significant economic repercussions of withdrawing without a deal, see generally: Freya Baetens, No Deal is Better than a Bad Deal? The Fallacy of the WTO Fall-Back Option as a Post-Brexit Safety Net, 55 C.M.L.R. 133 (2018).

${ }^{22}$ Theresa May, Prime Minister, Lancaster Speech on the Government's Negotiating Objectives for Exiting the EU (Jan. 17, 2017), https://time.com/4636141/theresa-may-brexit-speech-transcript/.

${ }^{23}$ The United Kingdom's Prime Minister's letter, supra note 14.

${ }^{24}$ Sunder Katwala, The Brexit Negotiations. What do the British Want?, FES (Nov., 2017), https://euagenda.eu/publications/ the-brexit-negotiations-what-do-the-british-want. See also Britain's Diplomatic Delusions, EconomisT (Aug. 23, 2018), https://economist.com/britain/2018/08/23/britains-diplomatic-delusions.
} 


\section{Pre-Notification Status of the Withdrawing State}

The first informal statement the EU27 gave after the British referendum, but still before official notification triggering Article 50 had been sent, established two connected principles which already strengthened the EU's negotiating power at the expense of the UK's. ${ }^{25}$ The first pre-notification principle was that, although it was up to the British government to notify the European Council of the UK's intention to withdraw, it should be done "as quickly as possible." In other words, the need to prepare for such complex talks which, once Article 50 is triggered, only guarantees the withdrawing state two years of negotiations-extension requires unanimity in the European Council-was counterbalanced by the uncertainty a long delay between public declarations and official notification could create for the remaining members. ${ }^{26}$

The second principle was "no negotiations before notification" despite nothing in the withdrawal clause banning informal discussions before notice. ${ }^{27}$ Without this second rule which the Union and all its Member States took very seriously during the Brexit process, a withdrawing country might seek certain advantages in conducting informal negotiations with the EU and extending de facto the short negotiation period. The EU27 did not allow this because Article 50's strict two-year timeframe, whilst an ally of the EU, is a pressure on the withdrawing state to accept the former's demands before its negotiating time is up. Likewise, a withdrawing state might try to hold talks with other members individually and undermine the Union's negotiating strength as a bloc. This too was avoided by the Union's determination to remain united, "quite to the surprise of many in London." 28 Indeed, without these two opportunities which the UK tried to take advantage of to no avail, the PM announced that Britain would be triggering Article 50 before the end of March 2017. ${ }^{29}$ It is widely agreed the UK was handicapped from the start by these pre-notification principles which left it in a weakened position and with little time to prepare for the complexity and seriousness of its exit procedure. ${ }^{30}$

\section{The Structure of the Withdrawal Talks}

There being no precedent, the frugal regulation of Article 50 TEU continued to offer generous room for interpretation with regards to the structure of the withdrawal talks, that is, what withdrawal negotiations should actually entail. Paragraph 2 of Article 50 simply states that: "In the light of the guidelines provided by the European Council, the Union shall negotiate and conclude an agreement with that State, setting out the arrangements for its withdrawal, taking account of the framework for its future relationship with the Union." The parties made very different readings of this vague sentencing. However, because the talks were to be held "[i]n the light of the guidelines provided by the European Council," it would necessarily be the EU's structuring of the negotiations that would prevail over the UK's.

The UK government, unable to pre-negotiate its departure with the EU or individually with the other Member States, used the nine months between the Brexit referendum and its Article 50 notification to sketch out its negotiating position. The most relevant of its early position papers was called The United Kingdom's Exit from and New Partnership with the European Union White

\footnotetext{
${ }^{25}$ Press Release, EU27, Statement by the EU27 at informal meeting (Jun. 29, 2016), https://www.consilium.europa.eu/ media/20462/sn00060-en16.pdf.

${ }^{26}$ Mauro Gatti, Article 50 TEU: A Well-Designed Secession Clause, 2 Eur. PAPERs 159, 179 (2017).

${ }^{27}$ Holger Hestermeyer, How Brexit Will Happen: A Brief Premier on EU Law and Constitutional Law Questions Raised by Brexit, 33 J. INT'L. ARB. 429, 438 (2016).

${ }^{28}$ Hussein Kassim, The EU Institutions, in Article 50 One Year On 30-32 (Anand Menon ed., 2018).

${ }^{29}$ Theresa May, Prime Minister of the United Kingdom, Address at the Conservative Party Conference in Birmingham (Oct. 2, 2016).

${ }^{30}$ Ivan Rogers, 9 Lessons IN BREXIT 32-44 (Short Books Ltd. ed., 2019).
} 
Paper." 31 The name itself reveals a first understanding of how Article 50 was expected to work by the British who hoped "to have reached an agreement about our future partnership by the time the two-year Article 50 process has concluded." 32 In effect, of the twelve principles set out in the White Paper, only the last dealt with the actual exit while the other eleven were a confusing description of the UK's "new partnership" with the EU. ${ }^{33}$ Unfortunately for the UK, its intention of negotiating the future relationship within the withdrawal agreement under Article 50 was not accepted by the Union. The European Council President's answer to May's letter made extremely clear that parallel talks were ruled out. ${ }^{34}$ On the contrary, the EU understood that where Article 50(2) required negotiations on the arrangements for "withdrawal, taking account of the framework for its future relationship with the Union," it meant that these talks were to be aimed solely at concluding an agreement on matters necessary to ensure an orderly withdrawal. The future relationship, on the other hand, could only be dealt with as a preliminary framework which had to materialize fully in a new set of negotiations once the UK had become a third country, that is, once its Article 50 TEU withdrawal agreement had entered into force. ${ }^{35}$

Both the UK and the EU's opposing interpretations of Article 50(2) TEU find support in the doctrine which had already discussed whether the future relationship should be negotiated in parallel with the withdrawal agreement or if such negotiations had to be left for after the latter was concluded. For example, it was the idea of Kreilinger Becker, and Wolfstädter that: "The course of the negotiations is not defined in legal terms. In fact, negotiations on the withdrawal arrangements, the future relationship and internal adjustment or reform arrangements can take place simultaneously." 36

Others believed, on the contrary, that Article 50 does not provide a basis for concluding a comprehensive treaty governing the future relationship. To begin with, the two-year negotiating period established by Article 50 suggests that it is not meant to cover the added complexity of such negotiations. This argument is reinforced by the fact that a withdrawal agreement is concluded by the Council by a specific majority which does not coincide with the voting methods used by the general rules for trade deals between the EU and third countries, namely, Articles 207, 218, or 217 TFEU. Thus, substantial tension would be created between Article 50 and these other provisions if a withdrawal agreement could cover the same content by means of a different procedure. $^{37}$

What is important is to understand how crucial the ordering of the negotiations is for the balance of power within them. ${ }^{38}$ The European Council Guidelines replaced the UK's parallel approach with a phased one, separating orderly withdrawal from future trade by refusing to open preliminary discussions on the future relations until it had secured an acceptable withdrawal deal:

\footnotetext{
${ }^{31}$ Department for Exiting the European Union White Paper on The United Kingdom's Exit from, and New Partnership with, the European Union (Feb. 2, 2017), https://www.gov.uk/government/publications/the-united-kingdoms-exit-from-and-newpartnership-with-the-european-union-white-paper.

${ }^{32} I d$. at 65 .

${ }^{33}$ Michael Emerson, After the UK's Brexit White Paper - What's the Next Move Towards a CFTA?, CEPS (Feb. 27, 2017), https://ceps.eu/ceps-publications/after-uks-brexit-white-paper-whats-next-move-towards-cfta/. Also, see generally Polly $\mathrm{R}$. Polak, Brexit: Theresa May's Red Lines Get Tangled up in Her Red Tape. A Commentary on the White Paper, 2 EuR. PAPERS 403 (2017).

${ }^{34}$ Press Release, European Commission, Remarks by President Donald Tusk on the next steps following the UK notification (Mar. 31, 2017), https://consilium.europa.eu/en/press/press-releases/2017/03/31/tusk-remarks-meeting-muscat-malta/.

${ }^{35}$ Council Guidelines, supra note 16.

${ }^{36}$ Valentin Kreilinger, Sophia Becker \& Laura Maria Wolfstädter, Brexit Negotiation Phases and Scenarios of a Drama in Three Acts, JACQUES DeLORS INST. 7 (Jan. 25, 2017) https://institutdelors.eu/en/publications/brexit-negotiation-phases-andscenarios-of-a-drama-in-three-acts/.

${ }^{37}$ Other arguments in favor of a narrow role for the withdrawal agreement can be found in Jens C. Damman, A Little Bit Brexit? An Analysis of the Rules Governing Post-Withdrawal Treaties, 53 TEx. INT'L. L. J. 153 (2018).

${ }^{38}$ See generally Paul Craig, The Process: Brexit and the Anatomy of Article 50, in The LAW AND Politics Of BREXIT 49 (Federicco Fabbrini ed., 2017) (emphasis added).
} 
We stand ready to engage in preliminary and preparatory discussions to this end in the context of negotiations under Article 50 TEU, as soon as the European Council decides that sufficient progress has been made in the first phase towards reaching a satisfactory agreement on the arrangements for an orderly withdrawal. ${ }^{39}$

Just as importantly, the EU chose the material issues that required priority attention: Citizens' rights, a financial settlement, and a solution to the Irish border. Although we must admit that it was mostly justified by the importance of such issues, focusing solely on these questions for the entire duration of the first phase talks was mainly a political choice as Article 50 simply refers to "arrangements for withdrawal."

The UK strongly favored parallelism because it would have enabled it to engage in trade-offs between what was now considered "terms of withdrawal" and the terms of the future relationship. This would have given it a much stronger negotiating hand because it would have included talks on security cooperation and other affairs in which the UK is undoubtedly a strong player ${ }^{40}$ instead of trading away citizens' rights and other bargaining chips simply in order to get the future talks started. In conclusion, by introducing this conditionality that, again, is not specified in the letter of the withdrawal clause, the EU clearly strengthened its own position and enhanced the probability of both resulting agreements being in line with its interests. ${ }^{41}$ Indeed, the "sufficient progress" formula was vague enough to allow the EU to freely decide when future trade talks could begin. Given the tight two-year schedule and the importance for the withdrawing state to move on to trade and offer some certainty to markets and businesses back home, concessions on withdrawal, as we are about to recall, became unavoidable. The other significant consequence was that these bargaining chips would then be missing from the UK's arsenal of negotiating tools in the future talks. Two birds with one stone.

\section{The UK's Red Lines Versus Its Withdrawal Agreement and Their Impact on the Future Trade Talks}

The strongest of the UK's withdrawal ambitions or "Brexit red lines" were declared by the UK Government soon after the referendum. ${ }^{42}$ In essence, Theresa May considered that her mandate was for the UK to achieve judicial independence from the Court of Justice of the EU ("CJEU" or "the Court"), to regain its power to make its own external trade deals by leaving the EU customs union, and to put an end to the free movement of people. ${ }^{43}$ This last red line clashed with one of the EU's own non-negotiable principles, namely, the indivisibility of the four freedoms, and therefore May also accepted the UK would have to be taken out of the internal market.

The opening meeting of the Brexit negotiations took place on June 19, 2017. The Terms of Reference begrudgingly agreed to by the British included a phased approach and a material content that reflected the EU's preferences. They established two initial negotiating groups on citizens' rights and the financial settlement and launched a dialogue on Ireland/Northern Ireland. ${ }^{44}$ These are the three substantive pillars of the WA we will focus on to see how the EU's understanding of

\footnotetext{
${ }^{39}$ Council Guidelines, supra note 16 , at 4 .

${ }^{40}$ See Ramses A. Wessel, Post-Brexit Participation of the UK in EU Foreign, Security and Defence Policy, in RESEARCH HANDBook on the InTERnAtional Dimension of BreXit (Ramses A. Wessel et al. eds., 2020).

${ }^{41}$ See generally Emily Jones, The Negotiations: Hampered by the UK's Weak Strategy, EUR. J. LEGAL STUD. 23 (2019).

${ }^{42}$ Vaughne Miller, Research Briefing, Brexit: Red Lines and Starting Principles, House Of COMmONS Library (Jun. 22, 2017), https://commonslibrary.parliament.uk/research-briefings/cbp-7938/.

${ }^{43}$ Theresa May, Speech supra note 22. See also Pascale Joannin, Organising Brexit, Foundation Robert SCHUMAn (Mar. 14, 2017), https://robert-schuman.eu/en/doc/questions-d-europe/qe-425-en.pdf.

${ }^{44}$ European Union, Terms of Reference for the Article 50 TEU Negotiations (Jun. 19, 2017) https://ec.europa.eu/info/sites/ default/files/eu-uk-art-50-terms-reference_agreed_amends_en.pdf.
} 
Article 50 severely conditioned the outcome of the UK's withdrawal process as well as constricted its negotiating power far into the future.

\section{Citizens' Rights}

The UK's determination to depart from the free movement of persons regime stemmed from the significant role immigration played in the Brexit referendum. In turn, this red line made it necessary to address and prioritize the situation of prior residents, that is, nationals of other EU states resident in the UK and British citizens in the EU27-together with qualifying family membersas they would no longer be able to depend on their residence rights derived from EU citizenship after Brexit. ${ }^{45}$

At the end of May 2017, the Commission's Article 50 Task Force (TF50) published a Working Paper containing the main principles of the EU negotiating position in regard to citizens' rights. The starting point was, in essence, to conserve the same level of protection enjoyed under EU law and the principle of equal treatment prior to the withdrawal date. Concerning the scope of the protection, these rights should be protected for life and be directly enforceable before the CJEU. Finally, regarding proof of residence, the EU called for simple national administrative procedures of a mere declaratory nature to obtain residence documents. ${ }^{46}$

The Union's opening offer was met with a UK position that deviated in important areas from that outlined by the Commission. On June 26, 2017, the UK Government published a Policy Paper focused mostly on the need for EU citizens to apply for residence or so-called "settled status" to continue residing legally in Britain. The result of achieving settled status would be a British imitation of EU equal treatment, although subject to the EU citizen remaining resident, that is, without an absence of more than two years from the country. However, the UK was willing to offer permanent right of return for settled EU citizens in the UK in exchange for onward movement rights for UK nationals who, living within the EU27, wished to move to another Member State after Brexit.

Another clear point of contention concerned family members. The UK intended that future spouses who wanted to go to the UK after Brexit be subject to the same rules that apply to non-EU nationals joining British citizens or, alternatively, to the post-exit immigration arrangements for EU citizens arriving after withdrawal. In a similar vein, only children born in the UK and not in the EU to EU citizen parents covered by the WA would be eligible to acquire settled status as a family member. The May Government was also adamant about upholding their biggest red line in this and in all other contexts: The CJEU was not to have jurisdiction in the UK. Similarly, the rights enshrined in the WA would be implemented through UK law, and the treaty would have the status of international law, that is, not the direct effect or supremacy that characterize the EU legal order. ${ }^{47}$

After months of painfully slow progress, as the negotiators began to run out of time, Mrs. May finally acknowledged something that had been carelessly dismissed by the UK until that point: That a transition period of continued application of EU law in the UK would also need to be put in place to avoid plunging the country into an ominous legal void once withdrawal became

\footnotetext{
${ }^{45} \mathrm{An}$ analysis of campaign and survey data that measures the importance of concerns about immigration and multi-culturalism had among leave voters in the Brexit referendum can be found in Sara Hobolt, The Brexit Vote: A Divided Nation, a Divided Continent, 23 J. Eur. PuB. Pol'Y 1259 (2016). See also Matthew Goodwin \& Caitlin Milazzo, Taking Back Control? Investigating the Role of Immigration in the 2016 Vote for Brexit, 19 BRIT. J. POL. INT'L. ReL. 450 (2017).

${ }^{46}$ European Commission, Essential Principles on Citizens' Rights (May 24, 2017), https://ec.europa.eu/commission/sites/ beta-political/files/citizens-rights-essential-principles-draft-position-paper_en.pdf.

${ }^{47} \mathrm{UK}$ Government, The United Kingdom's Exit from the European Union: Safeguarding the Position of EU citizens Living in the UK and UK Nationals Living in the EU (June 26, 2017), https:/gov.uk/government/publications/safeguarding-the-position-of-eucitizens-in-the-uk-and-uk-nationals-in-the-eu/the-united-kingdoms-exit-from-the-european-union-safeguarding-the-position-ofeu-citizens-living-in-the-uk-and-uk-nationals-living-in-the-eu.
} 
final, but the future agreement was still not in place. ${ }^{48}$ The EU had already decided transition had to be part of the WA and must be negotiated in the framework of Article 50 TEU but not before the three pillars had been settled. ${ }^{49}$ This added another essential matter to an already tight negotiating agenda and put further pressure on the UK to accept the EU's terms in phase one in order to start negotiations on a much needed transition deal as well as on the framework of the future relations. ${ }^{50}$ Under such pressure their positions on citizens' rights finally aligned as follows.

Part Two of the Withdrawal Agreement is dedicated to Citizens' Rights. ${ }^{51}$ The guiding tenet strongly resembles the EU's position: Lifelong reciprocal protection of residence rights under the principle of non-discrimination for those citizens of the EU27 in the UK and UK citizens in the EU who have exercised their free movement rights by the end of the transition period, or December $31,2020 .^{52}$ There is only one clear area in which the UK had its initial intentions respected: The EU conceded that it would be left up to each Member State and the UK to choose between a declaratory or a constitutive system of residency, and thus the UK continues to require Union citizens to apply for settled status. ${ }^{53}$ Concerning future family members, it is safe to say the UK met the EU halfway. Britain finally accepted that the future children of citizens covered by the WA could acquire the same rights whether they were born inside or outside the host state. However, this exception made for direct descendants does not extend in such generous terms to other relatives. In order for these to derive rights from a protected EU or UK citizen, they need to have the condition of family member at the end of the transition period. Those who become family members afterwards, for example, future spouses, will be subject to national law. ${ }^{54}$ The UK accepted the export of benefits as set out in EU law, including child support. ${ }^{55}$

EU citizens residing in the UK before the end of the transition period were now protected under the WA and could not be used as bargaining chips by the UK in the trade talks. What is more, some of the biggest concessions made by the UK in this first stage related to matters of governance of the WA, especially concerning citizens' rights. The UK has accepted that the entire Agreement is to have direct effect and supremacy over national law. They have also agreed to continued jurisdiction of the CJEU. In this sense, the WA requires provisions referring to Union law to be interpreted and applied in conformity with the relevant case-law of the Court. ${ }^{56}$ More specifically, it allows preliminary references to be requested by UK courts to the European Court within eight years from the end of the transition period when a case concerns Part Two on citizens' rights. ${ }^{57}$ Although seemingly random, this window is designed to give the Court time to develop a strong body of case-law to avoid any deviances in the protection of Brexit

\footnotetext{
${ }^{48}$ Theresa May, Prime Minister, PM's Florence Speech: a New Era of Cooperation and Partnership Between the UK and the EU (Sept. 22, 2017), https://www.gov.uk/government/speeches/pms-florence-speech-a-new-era-of-cooperation-andpartnership-between-the-uk-and-the-eu.

${ }^{49}$ Council Directive 21016/17 BXT ADD 1 REV 2 of May 22, 2017, Directives for the Negotiation of an Agreement with the United Kingdom of Great Britain and Northern Ireland Setting out the Arrangements for its Withdrawal from the European Union (EC).

${ }^{50}$ Michael Emerson, Stocktaking after Theresa May's Brexit Speech in Florence. Key point - The Transition, Key Omission the Future Relationship, CEPS (Sept. 2http6, 2017), s://ceps.eu/node/13036.

${ }^{51}$ For a more at length discussion on citizens' rights and withdrawal see generally Luis N. González Alonso, Los ciudadanos frente al Brexit o el inicio de una nueva batalla por los derechos, 19 ANUARIO DE LOS CURSOS DE DERECHOS HUMANOS DE Donostia-San Sebastián 57 (2019).

${ }^{52}$ The Withdrawal Agreement, EU-UK, art. 126, Oct. 17, 2019.

${ }^{53} \mathrm{Id}$. at art. 18. According to the UK Government website, the deadline to apply is June 30, 2021. United Kingdom, Apply to the EU Settlement Scheme (Settled and Pre-Settled Status), https://gov.uk/settled-status-eu-citizens-families.

${ }^{54}$ The Withdrawal Agreement, supra note 52, at art. 10.

${ }^{55} I d$. at art. 30.

${ }^{56}$ Although CJEU case law handed down after the transition period only needs to be given "due regard" by UK courts. See The Withdrawal Agreement, supra note 52, at art. 4(5).

${ }^{57}$ The Withdrawal Agreement, supra note 52, at art. 158(1).
} 
citizens on the two sides of the Channel. ${ }^{58}$ Regarding UK citizens in the EU, Barnier did not take up the offer of exchanging onward movement of UK nationals for return rights of EU nationals to the UK. After an absence of five consecutive years, their permanent residence is lost. ${ }^{59}$ By the same token, this issue has not been covered in the future trade deal, the new Trade and Cooperation Agreement between the EU and the UK (TCA). ${ }^{60}$ Thus, whilst EU citizens resident in Britain conserve their residence and equal treatment rights in the UK under the WA and, of course, continue to enjoy free movement in the rest of the Union under EU law, UK nationals can only depend on their WA rights in the host state in which they have exercised their right of residence before December 31, 2020. ${ }^{61}$ It would thus seem that despite this bargaining chip remaining in the hands of the EU throughout the trade talks, the UK was unwilling to grant any more concessions in return for onward movement. ${ }^{62}$

\section{Financial Settlement}

Britain's EU exit bill became an important obstacle to proceeding smoothly with the Brexit negotiations as round after round little to no progress was made in this area. Because Article 50 TEU is silent on the matter, a profound discrepancy existed regarding the nature or even the existence of a withdrawing state's obligation to pay the EU upon departure. Whereas it was the Union's view that Britain had made legally binding financial commitments which survived its withdrawal, the UK government challenged this assumption, going so far as to state that they would not be "blackmailed" by the EU over the financial cost of Brexit. ${ }^{63}$ There was also a special annoyance concerning the place it had been given in the sequencing of the talks that deliberately forbade the UK from using payment as leverage in discussions on trade. Thus, the Government continued to hamper on about the Union's refusal to talk about future trade relations. In the UK Brexit negotiator's opinion, the reason for this was not a legal one but a political set-up designed to "create pressure on us on money." 64

The British understanding of its outstanding financial obligations would ultimately prove irrelevant: The European institutions had made previous liabilities a compulsory part of EU withdrawal to be settled in the first phase of talks. Thus, when the negotiations broke down, the UK knew there was only one way to break the deadlock. Whatever its view on its legal responsibility, Theresa May assured EU members that they would not need "to pay more or receive less over the remainder of the current budget plan" and that the UK would honor "commitments we

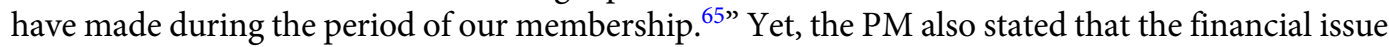
could only be resolved as part of a wider settlement on a transition period and the future EU-UK relationship. ${ }^{66}$ In other words, the UK, despite having conformed to the Article 50 Terms of Reference, had not given up hope of gaining leverage in the negotiations by linking the offer to pay its financial liabilities to matters of trade. ${ }^{67}$

\footnotetext{
${ }^{58}$ Michael Dougan, So Long, Farewell, auf wiedersehen, Goodbye: The UK's Withdrawal Package, 57 C.M.L.R. 631,675 (2020).

${ }^{59}$ The Withdrawal Agreement, supra note 52, at art. 14.

${ }^{60}$ Trade and Cooperation Agreement Between the European Union and the European Atomic Energy Community, of the One Part, and the United Kingdom of Great Britain and Northern Ireland, of the Other Part, Dec. 31, 2020, O.J. (L 444).

${ }^{61}$ The Withdrawal Agreement, supra note 52, at art. 9.

${ }^{62}$ Lisa O'Carroll, Britons in EU Urge Barnier not to Use Them as Bargaining Chips, ThE GUARDIAN (Jan. 27, 2020), https:// theguardian.com/politics/2020/jan/27/britons-in-eu-urge-barnier-not-to-use-them-as-bargaining-chips.

${ }^{63}$ Liam Fox Warns EU not to 'Blackmail' UK over Exit Bill, BBC NEWs (Sept. 1 2017), https://bbc.com/news/av/uk-politics41124729/liam-fox-warns-eu-not-to-blackmail-uk-over-exit-bill.

${ }^{64}$ David Davis on BBC One's Andrew Marr Show, BBC ONE (Sept. 3, 2017), https://bbc.co.uk/programmes/p05f114w.

${ }^{65}$ Theresa May, supra note 48.

${ }^{66} I d$.

${ }^{67}$ See generally House of Commons, Exiting the European Union Committee, The Progress of the UK's Negotiations on EU withdrawal - The Withdrawal Agreement and Political Declaration, HC 1778 (UK).
} 
The Commission's position remained unwavering: For “sufficient progress" to be made, the UK needed to specify exactly which financial commitments it was prepared to include in the settlement. ${ }^{68}$ The UK now had but a couple of weeks remaining to clarify its commitments or risk dragging the first phase negotiations into 2018. Finally, a Joint Statement issued by the two negotiators on December 8,2017, stated that agreement had been reached on the main elements and the methodology for the calculation of the financial settlement. ${ }^{69}$ An in-depth study carried out at the time by Sánchez-Barrueco found that " $[\mathrm{t}]$ he joint statement illustrates the imbalance between the two negotiating teams, showing that the UK has conceded the main demands made by the EU." the WA's Part Five dedicated to the financial provisions respects all of the EU's red lines: A single financial settlement to cover budgetary contributions, termination of membership of EU institutions and bodies, and participation in EU spending policies and programs, as well as asserting the euro as the sole currency for the financial settlement. Conversely, the UK showed no real negotiating power in this area. ${ }^{71}$ Initial Commission estimates for the Brexit divorce bill had been set at forty to sixty billion euros. ${ }^{72}$ After six months of British blustering, they were still positioned somewhere beyond forty-five billion. ${ }^{73}$ Once again, despite the UK's initial resistance, the pressure of the withdrawal process had proven unsurmountable. The EU had also known better than to hand the UK any bargaining chips for the future negotiations and adamantly refused to move on until the financial score was settled.

\section{The Protocol on Ireland/Northern Ireland}

The UK's withdrawal from the EU turned the land border between Northern Ireland and the Republic of Ireland into part of the EU's external frontier. This could have been a non-issue if the UK had decided to remain in the single market and customs union. However, depending on the future relationship between the EU and the UK, it could have meant going from an invisible border to the return of facilities for customs arrangements, regulatory checks, and control of individuals traveling between Northern and Southern Ireland. And this, beyond the important economic consequences of imposing such controls, ${ }^{74}$ would have carried the deeply symbolic implication of reinstating border checkpoints reminiscent of the fortified

\footnotetext{
${ }^{68}$ Michel Barnier, Speech Following the Sixth Round of Article 50 Negotiations with the United Kingdom (Nov. 10, 2017), https://ec.europa.eu/commission/presscorner/detail/en/SPEECH_17_4545.

${ }^{69}$ European Commission, Joint Report from the negotiators of the European Union and the United Kingdom Government on progress during phase 1 of negotiations under Article 50 TEU on the United Kingdom's orderly withdrawal from the European Union, TF50 (Dec. 8, 2017).

${ }^{70}$ Sánchez Barrueco, Leaving the EU budget: Brexit and Mutual Financial Claims, 18 ERA ForUM 453, 460 (2017).

${ }^{71}$ For a more detailed account of the financial settlement, including the Union's initial position and the content of the WA, see Matthew Keep, Brexit: The Financial Settlement - in Detail, House OF Commons Library (Mar. 16, 2020), https:// commonslibrary.parliament.uk/research-briefings/cbp-8039/.

${ }^{72}$ UK faces Brexit Bill of up to $€ 60 b n$ as Brussels Toughens Stance, Financial Times (Nov. 14, 2016), https://www.ft.com/ content/480b4ae0-aa9e-11e6-9cb3-bb8207902122.

${ }^{73}$ Brexit Bill Could Rise Beyond UK Estimate of $€ 40 b n-€ 45 b n$, FinANCIAL Times (Dec. 8, 2017), https://www.ft.com/content/ dfa27242-dc3a-11e7-a039-c64b1c09b482.

${ }^{74}$ At the time of the negotiations, seventeen percent of the Republic of Ireland's exports of goods and services went to Britain, the highest single reliance upon British purchases of any EU country. Likewise, the EU represented North Ireland's largest export market, with thirty-four percent of those exports going to the Irish Republic. See Jonathan Tonge, Briefing to European Parliament, The Impact and Consequences of Brexit for Northern Ireland, (Mar. 3, 2017), https:// europarl.europa.eu/thinktank/en/document.html?reference=IPOL_BRI(2017)583116.
} 
architecture constructed to contain the political violence of the so-called "Troubles" with similar installations targeted for some thirty years by the Irish Republican Army. ${ }^{75}$

Understandably, therefore, for the EU and the Irish Government ensuring an open Irish border by respecting the 1922 Common Travel Area and the 1998 Good Friday Agreement was non-negotiable. The way they found to secure an invisible border was to make the UK resolve the dilemma of reconciling these aims with the UK's red lines of leaving the EU single market and customs union before allowing talks to move on. Indeed, it was on these terms that the Irish question became the downfall of May's WA, of her premiership with it, and very nearly impeded Brexit altogether.

In August 2017, the UK Government issued a position paper on Northern Ireland and Ireland. The paper's governing principles were to avoid the return of a border on the Island, to prevent the creation of new barriers between Northern Ireland and Great Britain, to protect the integrity of the EU customs union and single market, and to establish a new independent UK customs regime, internal market, and trade policy. The approach to resolve these apparent contradictions was to set up a new customs partnership involving the UK applying the EU's rules to all goods arriving in the UK intended for the EU by using "innovative and untested" technology to track where the items eventually ended up. ${ }^{76}$ The EU chief negotiator swiftly dismissed these "solutions" as unworkable and restated the rules of the game: Time was passing quickly, and nothing was agreed until everything was agreed. ${ }^{77}$

As we have seen, the European Council held in October 2017 did not deem sufficient progress had been made to advance to the much sought-after second phase of negotiations. Among other reasons, the British pledge to avoid an Irish border had not included credible parameters within which to achieve a seamless and frictionless border while placing the UK outside the customs union and single market without undermining them. ${ }^{78}$ In December, the EU27 finally allowed talks to move on to phase two by including continued discussions on the Northern Ireland border. However, this did not offer the UK the chance it had hoped for of gaining leverage with the future trade agreement. On the contrary, in order to really move onto negotiating the transition period and future framework, the EU required one of the biggest concessions of all on behalf of the UK: The Irish backstop. ${ }^{79}$

At the end of February 2018, before negotiations on transition, let alone trade, had begun in phase two, the European Commission wrote up a first draft Withdrawal Agreement, including a Protocol on Ireland/Northern Ireland. ${ }^{80}$ In it, the UK would agree to maintain full alignment with

\footnotetext{
${ }^{75} \mathrm{~A}$ moving depiction of the cycle of political and religious violence at the Irish border and the implications of Brexit can be found in Aziliz Gouez, Ireland on the Rocky Road to Brexit, JACQUES DELORS INST. 12 (Nov, 30, 2017), https://institutdelors.eu/ en/publications/ireland-on-the-rocky-road-to-brexit/:

The joint effects of the peace process and of European integration have helped to rebuild ties between cross-border communities torn by three decades of conflict, as well as enabling the physical, as much as the symbolic and emotional weight, of the border to gently wither away. 'The 27 concrete bollards at Lackey Bridge are smashed' wrote Eugene McCabe in 1996, and foundations are being poured for the new bridge. There is a feeling that it will never again be closed. That chapter is finished. Things are returning to normal. One can easily grasp, then, the psychological shock and symbolic regression that the current prospect of a restored physical border across the island of Ireland represents for Irish people. After so many years of efforts geared at removing barriers and bringing people together, Brexit does indeed appear to be going against the grain of history.

${ }^{76}$ UK Government, Northern Ireland and Ireland - position paper (Aug. 16, 2017), https://gov.uk/government/publications/ northern-ireland-and-ireland-a-position-paper.

${ }^{77}$ Michel Barnier, Press Conference Following the Third Round of Article 50 Negotiations with the United Kingdom (Aug. 31 , 2017), https://ec.europa.eu/commission/presscorner/detail/en/speech_17_3043.

${ }^{78}$ Council Conclusions, European Council (Art. 50) Meeting - Conclusions (Oct. 20, 2017), https://www.consilium.europa. eu/media/23512/20-euco-conclusions-art50.pdf.

${ }^{79}$ European Commission, Communication to the European Council (Article 50) on the State of Progress of the Negotiations with the United Kingdom under Article 50 of the Treaty on European Union, at 784 (Dec. 8, 2017), https://ec.europa.eu/info/ publications/communication-commission-european-council-article-50-state-progress-negotiations-united-kingdom-underarticle-50-treaty-european-union_en.

${ }^{80}$ European Commission Draft Withdrawal Agreement on the withdrawal of the United Kingdom of Great Britain and Northern Ireland from the European Union and the European Atomic Energy Community, February 28, 2018, TF50 (2018) 33 .
} 
those rules of the Internal Market and the Customs Union, which supported North-South cooperation, the all-island economy, and the protection of the 1998 Agreement. This would essentially grant Northern Ireland a special status by which it was kept in the EU customs union and single market whilst the rest of the UK left. In other words, the February draft shifted the border from inside the Island of Ireland to down the Irish sea. This was the backstop that would have to apply until the EU was satisfied with an alternative solution proposed by the British, which needed to equally ensure an open border. The day the draft was made public by the Commission, the UK PM stood up in the House of Commons and stated that "if implemented [it] would undermine the UK common market and threaten constitutional integrity of the UK by creating a customs and regulatory border down the Irish Sea and no UK PM could ever agree to it." Boris Johnson, then Foreign Secretary, solemnly nodded his head in approval behind her. ${ }^{81}$

In the end, an Irish backstop was inserted into May's November 2018 draft Withdrawal Agreement, but it was a new one that replaced the special arrangements for Northern Ireland with the full alignment of the whole of the UK with the EU internal market and customs union. ${ }^{82}$ Unsurprisingly, it never achieved the simple majority necessary to pass in the House of Commons. As the next UK PM Boris Johnson would crudely express to justify voting against it, during its withdrawal process, the UK had gone from wanting the best of both worlds to a deal that was "the worst of both worlds, by which we somehow leave the EU but end up being run by the EU." 83 Unsurprisingly too, Mr. Johnson's Brexit wishes would not fare much better under the Article 50 withdrawal process when he was elected into office.

The new UK PM's plan was to remove the Protocol on Ireland/Northern Ireland from the WA. ${ }^{84}$ The EU, however, reminded him it was down to the UK to come forward with other legally operational solutions that would meet the objective of protecting the all-island economy. Removing the backstop with no alternative was out of the question. Barnier once again insisted on the rules of the withdrawal process and on his strict mandate to negotiate an orderly withdrawal which supported the peace process on the island without undermining the EU legal order. ${ }^{85}$

The following week, the parties published one last version of the Withdrawal Agreement following revision of the Protocol on Ireland/Northern Ireland: ${ }^{86}$ The new WA sees the whole of the UK, including Northern Ireland, leave the customs union. However, although the latter remains part of the UK customs territory, in practice EU customs legislation continues to apply to Northern Ireland, that is, to all goods entering its territory if they risk entering the EU single market. In other words, this latest Irish Protocol is essentially a return to the EU's February proposal setting out special arrangements for Northern Ireland and placing a border in the Irish Sea, something that had been emphatically rejected by both May and Johnson just a year before. Nonetheless, the Protocol's complicated system making Northern Ireland a theoretical part of the UK's customs territory while in reality placing it in a different legal position to the rest of

\footnotetext{
${ }^{81}$ Theresa May: No UK PM Could Ever Agree with EU Draft, BBC NEws (Feb. 28, 2018), https://bbc.com/news/av/ukpolitics-43228485/theresa-may-no-uk-pm-could-ever-agree-with-eu-draft\#.

${ }^{82}$ Draft Agreement on the Withdrawal of the UK from the EU as Agreed at Negotiators' Level (Nov. 14, 2018), https://ec. europa.eu/commission/publications/draft-agreement-withdrawal-uk-eu-agreed-negotiators-level-14-november-2018including-text-article-132-text-subject-final-legal-revision-coming-days_en.

${ }^{83}$ Boris Johnson, We Must be Brave and Vote Down a Deal that Represents the Worst of Both Worlds, TELEGRAPH (Jan. 13, 2019), https://www.telegraph.co.uk/politics/2019/01/13/must-brave-vote-deal-represents-worst-worlds/.

${ }^{84}$ Theresa May, Records of debates that happened in the House of Commons main chamber, (July 25, 2019), https:// hansard.parliament.uk/commons/2019-07-25.

${ }^{85}$ European Commission, Statement by Michel Barnier at the European Parliament Plenary session (Oct. 9, 2019), https://ec. europa.eu/commission/presscorner/detail/en/statement_19_6055.

${ }^{86}$ European Commission, Consolidated Version of the Withdrawal Agreement Following Revision of Protocol on Ireland/ Northern Ireland and Technical Adaptations to Article 184 "Negotiations on the Future Relationship" and Article 185 "Entry into Force and Application" as Agreed at Negotiators' Level and Endorsed by the European Council, (Oct. 17, 2019), 66, https://ec.europa.eu/info/sites/default/files/consolidated_withdrawal_agreement.pdf.
} 
the UK, as well as no longer being a backstop but a permanent arrangement, allowed Johnson to argue that the entire UK was leaving the EU and sell the deal back home. ${ }^{87}$ However, Johnson paid a heavy price for the UK to have its own trade policy. Despite insisting that Northern Ireland will be included, the WA effectively places a border down the Irish Sea which, paradoxically, will become harder the more the rest of the UK exercises its regained sovereignty and diverges from EU customs union and single market rules. Proof of the inadequateness of this solution and its important impact on the future trade negotiations soon appeared in the form of the UK Internal Market Bill ${ }^{88}$ and can still be found today. During the future trade talks, the UK Government threatened to unilaterally reinterpret the Irish Protocol in a bizarre attempt to deviate from its unwanted obligations whilst also hoping to regain some of the negotiating power lost during the withdrawal process. ${ }^{89}$ Indeed, the UK desperately tried to continue using the Irish question as leverage in the trade talks and refused to acknowledge that this bargaining chip, along with so many others, had already been traded away just to get them started. With the EU-UK TCA now in place and nearly a year and a half after the Protocol came into force, the European Commission is currently considering the UK's latest proposal of unravelling and renegotiating the question of the Irish border. ${ }^{90}$

\section{E. Conclusions}

This Article has highlighted the restrictions that are placed on a Member State wishing to withdraw from the EU. The unprecedented application of the skeletal Article 50 clause during the UK's departure has required interpretation and gap-filling exercises that have mostly been carried out unilaterally by the European institutions. From the Brexit experience emerges a legal process inserted into the supranational spirit of the Treaties that requires a bona fide attempt at concluding a withdrawal agreement as a result of the principle of sincere cooperation. As far as setting a precedent and although the UK's case is undoubtedly idiosyncratic, ${ }^{11}$ Brexit leaves behind a sense of the limitations and constraints any potential withdrawing state might face, as well as the Union's extraordinary ability to capitalize on its Article 50 TEU advantages to the detriment of the other party. ${ }^{92}$

The proof is in the pudding: The status offered to citizens under the EU-UK WA is much closer to the Union's initial position than to Britain's red lines. Arguably, the safeguarding of these rights is weakened as they fall outside the more comprehensive protection provided by EU law. Nonetheless, from an international law perspective, the supranational protection offered by

\footnotetext{
${ }^{87}$ Simon Usherwood, Boris Johnson's Brexit Deal: What's in it and how is it Different to Theresa May's Version?, THE CONVERSATION (Oct. 17, 2019), https://theconversation.com/boris-johnsons-brexit-deal-whats-in-it-and-how-is-itdifferent-to-theresa-mays-version-125446.

${ }^{88}$ United Kingdom Internal Market Bill 2019-21, HC Bill [27]. See Steve Peers, How Does the Internal Market Bill Breach the EU Withdrawal Agreement?, Prospect MAG. (Sept. 10, 2020), https://prospectmagazine.co.uk/politics/internal-market-billbreak-international-law-brexit.

${ }^{89}$ Boris Johnson, Let's Make the EU Take Their Threats off the Table and Pass this Bill, The TelegraPH (Sept. 12, 2020), https://telegraph.co.uk/politics/2020/09/12/make-eu-take-theirthreats-table-pass-bill/. See also Tony Connelly, Brexit: Boris Johnson, State Aid and a 'Rushed' Treaty, RAIDIÓ TeILIFÍs ÉIREANN (Sept. 12, 2020), https://rte.ie/news/2020/0911/ 1164694-tony-connelly-brexit-update/.

${ }^{90} \mathrm{UK}$ Government, Northern Ireland Protocol: the way forward (July 2021), https://assets.publishing.service.gov.uk/ government/uploads/system/uploads/attachment_data/file/1004581/CCS207_CCS0721914902-001_Northern_Ireland_Protocol_ PRINT_1_2_.pdf For more see: Oliver Garner, The UK Command Paper on the Protocol on Ireland/Northern Ireland: Future Relationship à la carte?, BREXIT INSTITUTE NEWS (July 29, 2021) http://dcubrexitinstitute.eu/2021/07/the-ukcommand-paper/

${ }^{91}$ Thank you to Professor Tim Oliver for highlighting this important fact.

${ }^{92}$ Although it might also be noted that larger and more powerful Member States such as the UK may have stronger bargaining power than smaller EU Members. See Mark Dawson, Coping with Exit, Evasion, and Subversion in EU Law, GER. L.J. $51,53(2020)$.
} 
the WA, including the role of the CJEU, is extraordinary and unparalleled in its reach. ${ }^{93}$ Concerning the financial provisions, the UK went during its withdrawal process from denying it had any legal liability, to offering payment only if trade talks were opened up, to finally accepting the Commission's proposal almost in its entirety. The fact that the EU had made previous financial liabilities a compulsory part of any withdrawal agreement-which would also include much needed transitional arrangements - meant such an outcome was practically unavoidable. Finally, the inclusion of the most contentious issue of the WA, the Irish border, in first phase negotiations initially required the UK to sign up to the Irish backstop and cross its main single market and customs union red lines. Meanwhile, the Protocol finally approved involves Northern Ireland remaining subject to large parts of EU legislation with unavoidable checks down the Irish Sea, something Mr. Johnson himself had described not long before as an arrangement "no British Conservative government could or should sign up to" 94 and which he is still today attempting to renegotiate.

While the UK's bargaining power was weakened from the start of its withdrawal negotiations, it also failed to put pressure on the $\mathrm{EU}$ at the end of the process by threatening to override provisions of the WA. While some perceived the precarious state the future partnership talks were in so close to the end of transition as one final UK plan to squeeze last-minute concessions out of Brussels, ${ }^{95}$ this "strategy" was unlikely to work-especially if there was anything to learn from the past. ${ }^{96}$ Thus, although Michel Barnier later reiterated that Brexit was a lose-lose situation for all parties, ${ }^{97}$ when he announced the signing of the EU-UK TCA on Christmas Eve, he began his press conference by stating, "The clock is no longer ticking." ${ }^{8}$ It is, of course, too early to evaluate or compare the negative impact that the major trade-offs between market access and withdrawal, at the heart of this new partnership, will have on both the EU and the UK. ${ }^{99}$ But Barnier's final reference to the time pressure placed on the exiting country throughout the negotiations reminds us again of how the Union effectively designed the process to gain maximum leverage and is therefore likely to suffer a lesser extent of damage. ${ }^{100}$ It might also be a warning that the Union will continue to deploy its mighty collective power where necessary, be it during other potential withdrawals or even in the next coming stages of its new relationship with the UK.

\footnotetext{
${ }^{93}$ Stijn Smismans, EU Citizens' Rights Post Brexit: Why Direct Effect Beyond the EU is not Enough, 14 EUR. CONST. L. REV. 443, 444 (2018).

${ }^{94}$ Boris Johnson, Speech Delivered to the DUP Annual Conference in Belfast (Nov. 24 2018).

${ }^{95}$ Katya Adler, How Close to a Brexit Trade Deal are We?, BBC News (Nov. 27, 2020), https://www.bbc.com/news/worldeurope-55106114.

${ }^{96}$ Georgina Wright, UK Threats to Break International Law Make a Brexit Deal Even More Difficult, INST. FOR Gov'T (Sept. 14, 2020), https://www.instituteforgovernment.org.uk/blog/break-international-law-brexit-deal-difficult.

${ }^{97}$ Lionel Laurent, Macron and Merkel Get the Least Bad Brexit Option, BloOMBERG (Dec. 26, 2020), https://www. bloomberg.com/opinion/articles/2020-12-26/brexit-deal-the-eu-gets-the-least-bad-option.

${ }^{98}$ Michel Barnier, European Commission's Head of Task Force Relations with the United Kingdom, Remarks by Chief Negotiator Michel Barnier at the press conference on the outcome of the EU-UK negotiations (Dec. 24, 2020), https://ec. europa.eu/commission/presscorner/detail/en/SPEECH_20_2533.

${ }^{99}$ A piecemeal overview of the TCA is being published on Steve Peers EU Law Analysis Blog. Steve Peers, Analysis 3 of the Brexit Deal: Human Rights and EU/UK Trade and Cooperation Agreement, EU LAW ANALYsIS: EXPERT INSIGHT INTO EU LAW DEVELOPMENTS (Jan. 4, 2021), http://eulawanalysis.blogspot.com/.

${ }^{100}$ Brigid Laffan, Brexit has Enabled the EU to Reveal its Essential Essence, THE IRIsH Times (Jan. 12, 2020), https://www. irishtimes.com/opinion/brexit-has-enabled-the-eu-to-reveal-its-essential-essence-1.4455620.
}

Cite this article: Polak PR (2021). Who Had Their Cake and Ate It? Lessons from the UK's Withdrawal Process and its Impact on the Post-Brexit Trade Talks. German Law Journal 22, 983-998. https://doi.org/10.1017/glj.2021.54 